\title{
Role of Government in Environment-friendly Agricultural Development of Bangladesh
}

\author{
Islam, MD. Mafizul • Hwang, Hancheol \\ The Graduate School of International Development and Cooperation, Hankyong National University \\ *Dept. of Bioresource \& Rural Systems Engineering, Hankyong National University
}

\section{방글라데시의 친환경농업개발과 정부의 역할}

엠디 마피줄 이슬람・황한철*

한경대학교 국제개발협력대학원 • ${ }^{*}$ 한경대학교 지역자원시스템공학과

\begin{abstract}
요약 : 본 연구는 방글라데시의 친환경농업 실태와 농업인들의 인식을 바탕으로 친환경농업 개발에 대한 정부의 역할과 정 책적 대안을 모색하고자 하였다. 연구 자료는 방글라데시 탕가일 지역의 농업인을 대상으로 유기농가 100 가구와 일반농가 100 가구를 무작위로 추출하여 설문조사를 통하여 수집되었다. 인구 과밀의 방글라데시 정부는 식량안보를 위하여 지력 저 하 및 환경악화를 방지하고자 많은 노력을 기울이고 있다. 즉 지속 가능한 농업개발을 위하여 통합해충관리(IPM), 통합작물 관리(ICM)를 비롯하여 토양의 비옥도 개선, 페로몬트랩이나 자연 천적을 이용한 해충방제 등 다양한 프로그램을 운영하고 있다. 농업인들의 의견 조사에 따르면 친환경농업에 대한 정부의 역할은 긍정적으로 평가하고 있으나 정책이나 관련 프로 그램은 아직 부족한 것으로 나타났다. 일반농가인 경우 극히 소수 농가만이 친환경농업을 실행하고 있는데, 이는 관련기술 에 대한 지식의 부족과 유기농 비료 등의 자재 부족이 친환경농업을 실행하는데 가장 큰 어려움이라 지적하고 있다. 일반 농가의 $39 \%$ 는 유기농업 의사를 보이고 있지만 마케팅시설의 부족과 농사 실패에 대한 두려움 등을 유기농으로 전환하지 못하는 주요 이유로 들고 있다. 일반농가의 일부(17\%)만이 정부의 농업교육 프로그램임인 통합해충관리(IPM)과정을 이수하 고 있다. 정부의 유기농 정책은 거의 전무하며 $\mathrm{NGO}$ 들의 지원에 의하여 꾸준하게 진행되고 있을 뿐이다. 따라서 농업인들 은 통합해충관리(IPM), 유기농 퇴비, 페로몬트랩이나 자연 천적 등 매우 다양한 농민교육프로그램들을 정부 주도적으로 실 시하여야 하며 친환경농업정책을 보다 명확하게 규정하기를 요구하고 있다. 비교적 젊고 교육수준이 높은 소규모 농업인들 이 유기농에 적극적임을 알 수 있다. 유기농의 평균 농지규모는 $0.246 \mathrm{ha}$, 유기농 평균 경력은 7.63년, 일반농가대비 농가수 입은 $11.4 \%$ 높게 나타났고 비교적 소농들이 높은 수익률을 보이고 있다. 소비자의 신뢰, 마케팅시설, 생산자단체나 조직의 부족 등이 유기농가들의 가장 큰 애로점이 되고 있고, 유기농산품의 표준화를 위하여 정부의 인증제도와 인증기관 설립이 필요함을 지적하고 있다. 유기농을 보다 활성화하기 위해서는 정부 주도하에 마케팅을 비롯하여 교육, 수출 및 각종 장려 책 등이 마련되어야 할 것이다.
\end{abstract}

핵심용어 : 친환경농업개발, 정부역할, 농민 의사, 유기농가, 일반농가

\section{Introduction}

During the past several decades, visible improvements in agricultural productivity have been achieved in Bangladesh through so called Green Revolution. Agricultural production

Corresponding author : Hwang, Hancheol

Tel. : 031-670-5133

E-mail : hwang@hknu.ac.kr systems using high input and high-yield technology are the key driving forces of Green Revolution. Government has invested its maximum strength to ensure the food security of over growing population of Bangladesh. As a result, Bangladesh is facing countless challenges in agriculture sector in recent years which have directly or indirectly emerged from consequences of Green Revolution.

In the aspect of rural poverty and farmers' livelihood, 
Bangladesh has achieved little progress, but it is not satisfactory level compared to other South and South East Asian countries. According to the data of World Bank (2011), rural and urban poverty rates of Bangladesh in 1973-74 were 47.7 and 32.3 percent respectively where as in 2010, the rates were 35.2 and 21.3 percent. At the same time, food production increased from around 8 million tons in 1973-74 to over 31 million tons in 2009-10 (MOA, 2010). Food production increased around 4 times in that time due to heavy reliance on high input and high yield technology. This evidence of slow decreasing rural poverty rate of Bangladesh indicates that the ability of conventional agriculture to reduce rural poverty is questionable. Livelihood of conventional smallholder farmers who have no source of income from non-farm activities is worsening in maximum cases gradually.

On the other hand, environmentally friendly agriculture is beneficial for product's quality, human health, soil, environment and future generations, and also ensures sustainable agricultural development. Many scientists like Makatouni (2002); Vindigni et al. (2002); Hallam (2003) and Smith et al. (2004) who suggested to practice EFA for ensuring agricultural sustainability. Many recognized international organizations like, FAO, IFAD and IFOAM, and many scientists like Scialabba (2000); Setboonsarng (2006) and Pretty (2002) highly recommended for subsistence or smallholder farmers to practice organic agriculture to improve their farm profit as well as livelihood.

In Bangladesh, 62\% labor force being employed in agriculture sector (MOA, 2010) and maximum farmers are small, marginal and landless type who have less than 1.00 hectare of farmland. This large number of farmers can easily practice organic agriculture because they have abundant labor forces and experiences of long term farming. It has huge prospects to improve the livelihood of subsistence farmers of Bangladesh through catching the rapid expanding organic market in developed countries and also within the country. In the same time, Bangladesh can earn a lot of foreign currency with ensuring sustainable agricultural development.

It is a great challenge to the government of Bangladesh to ensure food security of this over populous country. On the other hand, Environmentalists are raising environmental issues that have never before been deemed so urgent.
Government of Bangladesh faces conflicting pressures: the need simultaneously to increase production of food and fibers, keep food prices within the reach of consumers and address environmental concerns. Considering the above mentioned crucial issues, government of Bangladesh has reformed its agricultural policies and has taken extensive programs on Integrated Pest Management (IPM), Integrated Crop Management (ICM), pest control using bio-agent and soil fertility improvement etc., but it has no specific initiatives to enhance organic agriculture. Many countries of the world are using organic agriculture sector as a tool of maintaining agricultural sustainability and poverty reduction. Therefore, this study focused on indentifying appropriate role of government to foster environment-friendly agriculture with given strong emphasis on organic agriculture for ensuring food security, agricultural sustainability, economic enhancement of farmers and poverty reduction of Bangladesh. This is apprehended that the findings of the study will promote greater awareness of the government's role in environment-friendly agricultural development that might be able to enhance establishing a baseline for sustainable agriculture and related policy analysis in Bangladesh. The study was conducted with the following specific objectives: i) to review the government's policies and programs on environment-friendly agricultural development in Bangladesh; ii) to assess the role of government of Bangladesh whether it has promoted or hindered environment-friendly agricultural development; iii) to find out farmers' attitudes toward government's role in environment-friendly agriculture in Bangladesh through case study analysis; and iv) to know the effect of organic agriculture on profitability of farmers as well as on rural livelihood of Bangladesh.

\section{Literature review}

\section{Environment-friendly agriculture}

The search for alternatives to modern agriculture harbored many names; including low-input agriculture, low external input sustainable agriculture, alternative agriculture, biological agriculture, organic agriculture, environmentfriendly agriculture, as well as, sustainable agriculture. Therefore, environment-friendly agriculture (EFA) is used as 
synonymous meaning of sustainable agriculture. In this study, EFA included low external input sustainable agriculture and organic agricultural practices which are not or less harmful to environment. A great deal of effort has gone into trying to define sustainability in absolute terms. Since the Brundtland Commission's definition of sustainable development in 1987, there have been at least 100 more definitions constructed, each emphasizing different values, priorities and goals. But precise and absolute definitions of sustainability, and therefore of sustainable agriculture, are impossible (Pretty, 1995a). Sustainability itself is a complex and contested concept. To some it implies persistence and the capacity of something to continue for a long time. To others, it implies not damaging or degrading natural resources (Pretty, 1995b). However, the American Society of Agronomy defines sustainable agriculture as " $\cdots$ one that, over the long term, enhances environmental quality and the resource base on which agriculture depends, provides for basic human food and fiber needs, is economically viable, and enhances the quality of life for farmers and society as a whole" (Vasavada, 1991).

\section{Sustainable Agricultural Development}

Sustainable agricultural development has become a key issue because of widespread and growing concern about the severity of the depletion of the world's natural resource base and an ever-increasing population pressure on these resources (Liu and Lu, 1992). The concept of sustainable agricultural development differs in its meaning between developed and less developed countries. In developed countries, sustainable agricultural development focuses on issues like organic farming, pollution from agricultural activities, and the like. In the case of less developed countries, the focus is on unsustainable resource use leading the soil erosion, declining crop yields and loss of soil productivity (Ming, 2003).

Different scientists define sustainability in different ways. Again it varies from issue to issue or depends on the condition of the surrounding environment. An economist may define sustainable development as living on interest and not on capital, but this fails to emphasize adequately the importance of the preservation of natural resources and the environmental aspects of sustainability. Sometimes a more comprehensive definition is needed (Greenland, 1997), such as that offered by Dumansky (1993). He refers specially to land management as: Sustainable land management combines technologies, policies and activities aimed at integrating socioeconomic principles with environmental concerns so as to maintain or enhance production; reduce the level of production risk; protect the potential of natural resources and prevent degradation of soil and water quality; be economically viable and be socially acceptable.

\section{Role of Government in Sustainable Agricultural Development}

According to the Rio Declaration, governments are given the leadership role in implementing sustainable development. The twenty-seven principles of the declaration delineated the general areas of responsibility and accountability, as well as outlining the strategic means for achieving sustainable development: by creating and integrating institutional, legal, and policy frameworks, and in promoting informed decision making, all of which gives critical consideration to the linkages between social, economic, and environmental factors, at the international, national, and local levels. The key resources for achieving sustainable development are new technologies, finance and investment, and public participation (or global partnership); the three are not mutually exclusive (Cheung, 1997).

The Brundtland Commission called on governing institutions to better address sustainable development issues. IISD (1995) recognizes that government activities and policies greatly influence the degree of progress which can be made towards sustainable development, and that much work remains to be done by governments themselves. Agenda 21 states that governments must adjust or reorient their policies to integrate environment and development in decision-making. Agenda 21, the action plan for sustainable development, provides a comprehensive approach to address the pressing environment and development problems of the day, and to prepare the world for the long-term challenges of sustainability in the twenty-first century. The Commission on Sustainable Development (CSD) was created in December 1992 to oversee, promote and support the implementation of Agenda 21 (UNCED, Agenda 21, 1992). 


\section{Resource poor small farmers and organic agriculture}

It is evident that $\mathrm{OA}$ can improve the incomes and living standards of poor farmers by building on assets which poor farmers have, i.e., land free from intensive use of chemicals, excess labor, and traditional knowledge of production system. Many of the poor farmers in remote areas possess a comparative advantage over farmers in intensive areas because the former's current practices are largely organic by default. Unlike their conventional counterparts, they will not require a transition period of 3-5 years before they can be certified organic. This gives them an edge in terms of immediately capturing the benefits of producing certified organic products for the domestic and international markets (Setboonsarng, 2006).

Most farmers in marginal areas practice traditional agriculture methods using very little or no agrochemicals. By adopting organic agriculture (OA), which requires less financial inputs while placing more reliance on natural and human resources, farmers could move towards more sustainable agricultural practices (Scialabba, 2000). This provides a case for donors and government to look more seriously into supporting $\mathrm{OA}$ as a development tool for this group of rural poor (Setboonsarng, 2006).

Organic agriculture is likely to benefit the poor living in marginal areas the most, by improving productivity and incomes, and promoting environmental sustainability. A study by Setboonsarng, et al. (2005) on organic rice contract farming likewise finds that small organic farms are more profitable and efficient than larger farms. IFAD's study in Latin America and the Caribbean (2003) reveals that OA has benefited smallholders the most.

\section{Farmers' profitability and organic agriculture}

Much of the increase in organic production is occurring in developing countries where farmers are being attracted by export benefits and substantial price premiums (RocSearch, 2004). Organic products enjoy price premiums of between 10-300 percent, depending on the product (Setboonsarng, 2004), and different studies estimate that farmers receive between 44-50 percent of the price premium (Stoll, 2002).

Employing organic farming methods leads to higher profits for farmers not only because of price premiums, but also because of lower production costs (von Braun, et al., 2003). OA technologies can decrease the costs of production as chemical inputs are substituted by locally available and cheaper organic inputs and more intensive labor which the poor often have in abundance. Adoption of OA systems also lowers the need for credit, which is often expensive and difficult to obtain for small farmers.

The relative profitability of organic production compared to conventional production tends to increase over time as a result of yield improvement after an initial decline. This phenomenon of initially declining and then improving yields following conversion from conventional to organic production is commonly observed in studies of organic agriculture, and occurs as soil fertility improves and as farmers learn how to adapt their production methods (Scialabba and Hattam, 2002)

\section{Research methodology}

First step of the research is the literature based study to review critically the policies and programs related to environment-friendly agriculture in Bangladesh. Second step is a primary data collection from Bangladesh to know farmer's attitude toward government's role in environmentfriendly agriculture. Primary data (both quantitative and qualitative) were collected through survey method and closed ended structured questions were asked to the respondents as personal (face to face) interview. Population of this study included conventional and organic farmers of Madhupur and Delduar sub-districts of Tangail district of Bangladesh. From this population 100 default organic farmers were selected randomly from Pirojpur and Kandapara villages of Madhupur and Delduar sub-district respectively. Another 100 conventional farmers were selected randomly from Kakraid and Atia which are the neighboring villages of Pirojpur and Kandapara.

Two sets of questionnaire (Set-A and B) were used to collect data from the conventional and organic farmers respectively. The same context of questions was given to all interviewees under each set and they received exactly the same interview stimulus. Questions were very specific with a fixed range of answers. Structured questionnaire had multiple-choice questions in which the researcher provided 
a choice of answers and respondents were asked to select one or more of the alternatives, and dichotomous questions that had only two response alternatives, yes or no. 'Likert Scale' (considered on 1-5 point's scale) also used to measure the farmer's responses based on few statements to perceive attitudes towards environment friendly agriculture and government's role on it. The points of the scale indicate the degree of satisfaction or agreement level of the respondents on the various issues related to environment friendly agriculture. ' 5 ' represents the highest level of satisfaction or high agreement, whereas ' 1 ' represents the lowest level of satisfaction or high disagreement.

Finally the data acquired were analyzed using descriptive statistics techniques and Pearson's correlation test with the Statistical Analysis System (SAS) software. Firstly variables are taken from excel sheets and then series of analysis are applied.

\section{Role of government of Bangladesh in environment-friendly agricultural development}

The government of Bangladesh has given strong emphasis on sustainable agricultural development. It encourages initiatives from any corner, either public or private in relation to the agricultural sustainability. Bangladesh recognizes the vital importance of participating in the global attempts to halt the process of environmental deterioration. The country has actively involved in the proceedings of the UNCED, signed the Rio declaration and endorsed Agenda 21. This reflects the strong commitment of Bangladesh towards promoting environmental management and sustainable development. The government has promulgated many policies, plans and programs in the natural resources sectors such as agriculture, water, fisheries, forestry, energy, public health and infrastructure to foster economic development while considering the environment.

The Government promulgated National Agricultural Policy in 1999 which provides guidelines for development activities related to crops, the largest sector of agriculture, calling for increased profitability from sustainable and diversified production systems for improved real income of farmers as well as food security and nutrition. The Ministry of Agriculture of the Government of Bangladesh amended "The Pesticide Rules 1985" which was published in "Bangladesh Gazette" in May 9, 2010. The newly modified policy will allow the registration of commercial production and marketing of biochemical pesticides including its distribution and use, which are an integral part of IPM methods.

The government of Bangladesh implemented many programs in relation to sustainable agricultural development in last two decades and currently some programs are running, likely:

\section{Integrated Pest Management in Bangladesh}

In Bangladesh, IPM activities first started in 1981 with the introduction of the first phase of FAO's inter-country program (ICP) on IPM in rice crop. However, it was in 1987 that IPM activities began to expand and became a popular topic among people from all walks of life. From 1989 to 1995 , the ICP played a strong catalytic role in promoting the IPM concept and approach among the government officials and donor community. This program provided IPM training to build the training capacity of the Department of Agricultural Extension (DAE) and introduced Farmer Field Schools (FFS) for training of farmers. A number of persons from the non-government organizations (NGOs) were also given training on IPM. Thus, with the strong support of the Government, an effective IPM base has already been established in Bangladesh (MOA, 2002).

\section{Integrated Crop Management (ICM)}

Integrated Crop Management (ICM) is a modern version of IPM approach. ICM integrated two approaches: "Integrated Pest Management" (IPM) and "Integrated Plant Nutrition System" (IPNS). IPM is "a sustainable approach to managing pests and crops by combining cultural, biological, genetic, mechanical and chemical methods in a way that minimizes economic, health, and environmental risks". The IPNS concept is "the management of all available plant nutrient sources, organic and inorganic, to provide optimum and sustainable crop production conditions within the prevailing farming system". 
3. Use of semiochemicals (pheromone traps) and bio-agents (natural enemies) to control pests of crops

The Government of Bangladesh has taken an extensive program on using pheromone traps and bio-agents to control pests of different crops. Department of Agricultural Extension (DAE) is distributing some parasitoids and pheromone traps to control specific insects of vegetables without any cost. In addition to this, government has taken some collaborative programs with native research institutes like, Bangladesh Rice Research Institute (BRRI), Bangladesh Agricultural Research Institute (BARI), donor agencies like, USAID, DFID, DANIDA, private company like, Syngenta (BD) Limited and some native NGOs to promote pest control of rice and vegetables using bio-agents and semiochemicals.

\section{Use of Organic manure for improving soil fertility.}

DAE has taken a vast program on preservation and using of cow-dung; making and using of compost, vermin compost and quick compost, and green manure (using legumes) to improve the organic matter content of soil as well as for improving soil fertility. Government provides financial incentives in some scale to set demonstration plots of organic manure. Sub Assistant Agriculture Officer (SAAO), the field staff of DAE motivates the farmers to use organic manure to improve soil fertility as their daily routine work. As part of the government's initiatives to improve and to maintain the soil fertility, a big collaborative project with DANIDA namely "Integrated Soil Fertility and Fertilizer Management Project (SFFP)" was successfully completed in 2006.

\section{Role of government in organic agriculture sector of Bangladesh}

In Bangladesh, NGOs are helping more than government to adopt organic farming. These NGOs organize interested farmers, provide training, technical advice and financial support, and help in marketing organic products. Although, total land area under organic cultivation has been estimated at 0.177 million hectares in Bangladesh (IFOAM, 2006), but till now, it has no clear policies on organic agriculture. Bangladesh has no government's certification body of organic products to ensure consumer's trust.

\section{Critical assessment of the Government' s role in EFA}

The Government of Bangladesh has showed its enthusiasm and commitment to the Multilateral Environmental Agreement (MEA) by signing and ratifying most of the MEAs and formulated several strategies and action plans to fulfill its international commitments and support national development (MOA, 2008). The Government has taken some programs and strategies likelyIPM, ICM, biological pest control, extensive use of manure, reducing subsidy in chemical fertilizers, no subsidy in pesticides etc. for sustainable agricultural development of Bangladesh. But these policies and programs are not sufficient compared to advanced agricultural countries.

The government of Bangladesh has no specified policies and programs on organic agriculture. Therefore, organic agriculture sector of Bangladesh is progressing steadily without any specified government's initiatives. Many countries in the world have already attained a significant development in certified organic farming where nearly 31 million ha of land are managed organically in 120 countries throughout the world and the market for organic foods and beverages was US\$ 40 billion in 2006 which is $2 \%$ of total food retail in the developed countries (Willer and Yussefi, 2007). Unfortunately, in this big organic market the share of the developing countries like Bangladesh is really very little. Though many researchers like Kilcher (2002), Mc Neely and Scherr (2002), and Yussefi and Willer (2003) strongly recommended that organic agriculture is not just a resolution for more wealthy countries but also effective in poorer countries and it can give them purposeful socio-economic and ecologically sustainable development.

Bangladesh is a marginal food surplus country and it is situated in natural disaster prone area. Therefore, any time any calamity can make this as a food deficit country. It is generally thought that organic agriculture reduces the yield at the first time compared to high input inorganic agriculture. For this general thinking, government probably does not take any courageous initiatives on organic 
Role of Government in Environment-friendly Agricultural Development of Bangladesh

Table 1 Basic characteristics of conventional and organic farmers

\begin{tabular}{|c|c|c|c|}
\hline \multirow[b]{2}{*}{$\begin{array}{l}\text { Explanatory variable with } \\
\text { measurement unit }\end{array}$} & \multirow[b]{2}{*}{$\begin{array}{l}\text { Farmer' s group based on } \\
\text { their characteristics }\end{array}$} & \multicolumn{2}{|c|}{ Number of respondents } \\
\hline & & $\begin{array}{c}\text { Conventional farmers } \\
\text { (Total number of farmers } \\
\mathrm{N}=100 \text { ) }\end{array}$ & $\begin{array}{c}\text { Organic farmers } \\
\text { (Total number of farmers } \\
\mathrm{N}=100 \text { ) }\end{array}$ \\
\hline Age (Number of years) & $\begin{array}{c}\text { Young }(18-25) \\
\text { Middle aged }(26-40) \\
\text { Old }(41-55) \\
\text { Very old }(>55)\end{array}$ & $\begin{array}{c}4 \\
17 \\
48 \\
31\end{array}$ & $\begin{array}{c}5 \\
42 \\
37 \\
16\end{array}$ \\
\hline $\begin{array}{c}\text { Literacy level (Years of } \\
\text { schooling) }\end{array}$ & $\begin{array}{c}\text { Illiterate }(0) \\
\text { Primary }(1-5) \\
\text { Secondary }(6-10) \\
\text { Higher secondary and } \\
\text { above }(>11)\end{array}$ & $\begin{array}{l}24 \\
50 \\
18 \\
8\end{array}$ & $\begin{array}{c}13 \\
44 \\
37 \\
6\end{array}$ \\
\hline $\begin{array}{l}\text { Farmers category on farm } \\
\text { size (Amount in hectare) }\end{array}$ & $\begin{array}{c}\text { Landless }(\langle 0.02) \\
\text { Marginal }(0.02-0.20) \\
\text { Small }(0.21-1.00) \\
\text { Medium }(1.01-3.00) \\
\text { Large }(>3.00)\end{array}$ & $\begin{array}{c}15 \\
33 \\
23 \\
24 \\
5\end{array}$ & $\begin{array}{c}3 \\
28 \\
58 \\
9 \\
2\end{array}$ \\
\hline
\end{tabular}

agriculture. But, in the US, the top $25 \%$ of sustainable agriculture farmers practicing 'organic farming' have better gross margins and better yields than the top $25 \%$ of their counterparts still practicing chemical agriculture (Anonymous, 1980). Scialabba and Hattam (2002) also reported that improved yields were found in organic agriculture after conversion period.

Overall assessment is that government of Bangladesh is playing positive role in sustainable agricultural development but it is relatively inadequate. Like any other advanced agricultural country, it needs more effective policies and programs in environmentally friendly agriculture sector to ensure sustainable agricultural development of Bangladesh.

\section{Results and discussions}

Primary data were collected from conventional and organic farmers. Therefore, results were also obtained from conventional and organic farmers.

\section{Basic characteristics of conventional and organic farmers}

Results shown in table 1 indicate that comparatively young, educated and small farmers practiced organic farming. Characteristics of conventional farmers were more or less similar to the Bangladeshi general farmers.

\section{Results from conventional farmers}

Government of Bangladesh has taken different initiatives on EFA including training programs. This study tried to indentify the sources of farmers' training which is one of the main programs related to EFA and to know conventional farmers' perceptions on government's role in EFA.

Similar to other developing countries, technical

Table 2 Sources of farmers training on EFA

\begin{tabular}{|c|c|c|c|c|c|}
\hline Subjects & $\begin{array}{c}\text { Farmers' } \\
\text { responses (Yes/No) }\end{array}$ & $\begin{array}{c}\text { Number of } \\
\text { respondents }(\mathrm{N}=100)\end{array}$ & $\begin{array}{c}\text { Sources of receiving } \\
\text { training }\end{array}$ & $\begin{array}{l}\text { Number of } \\
\text { respondents }\end{array}$ & Percentage \\
\hline Training on EFA & $\begin{array}{l}\text { Yes (Positive) } \\
\text { No (Negative) }\end{array}$ & $\begin{array}{l}22 \\
78\end{array}$ & $\begin{array}{c}\text { DAE } \\
\text { NGO } \\
\text { Others }\end{array}$ & $\begin{array}{c}22 \\
0 \\
0\end{array}$ & $\begin{array}{c}22 \\
0 \\
0\end{array}$ \\
\hline Training on IPM & $\begin{array}{l}\text { Yes (Positive) } \\
\text { No (Negative) }\end{array}$ & $\begin{array}{l}17 \\
83\end{array}$ & $\begin{array}{l}\text { DAE } \\
\text { NGO } \\
\text { Others }\end{array}$ & $\begin{array}{c}17 \\
0 \\
0\end{array}$ & $\begin{array}{c}17 \\
0 \\
0\end{array}$ \\
\hline
\end{tabular}


knowledge of conventional farmers of Bangladesh is low and training is essential to improve their knowledge level. Considering the importance of farmers' training on EFA, government has taken extensive training program on EFA and IPM. Result in table 2 shows that only $22 \%$ farmers had received training on EFA and the source of training was Department of Agricultural Extension (DAE) which is an organization of government. Here, training on EFA includes training on IPM, ICM, soil fertility improvement technologies and other environment friendly agricultural technologies. Result also indicates that only $17 \%$ farmers had received training on IPM from same source DAE (table 2). It needs a clarification that some government's organizations including DAE and several NGOs provide EFA and IPM related training to farmers in Bangladesh. In this study area, no other GO and NGO were providing such kinds of training. Therefore, only DAE was the source of providing training on EFA and IPM to farmers.

Bangladesh is a developing country, and its government has financial and other limitations. In spite of those limitations, government has taken different programs and promulgated policies in favor of EFA. Government's initiatives proved its positive attitude toward EFA. It was also reflected in farmers' opinion (shown in table 3) since majority of farmers are agreed (43\%) and strongly agreed (10\%) "Government plays a positive role in EFA". According to the farmers' opinions, the average value of Likert scale (Likert value) 3.27 indicated that "Government has positive role in EFA".

On the other hand, majority of farmers disagreed (strongly disagree $25 \%$ and disagree 39\%) that "government's policies and programs are sufficient for EFA". The Likert value 2.21 mentioned that farmers were disagreed about "government's policies and programs are sufficient for EFA". Therefore, the results from this study indicate that government of Bangladesh plays a positive role in EFA but its policies and programs are not sufficient for EFA. In this aspect, farmers suggested some policies and programs for government's initiatives which are shown in table 4. Among the suggestions, the highest number of farmers (64 respondents) suggested for government's initiatives to take extensive training programs on EFA. This result is the clear reflection of farmers' necessity of technical knowledge of EFA. Farmers gave 2nd priority (58 respondents) as their suggestion to take extensive programs on IPM and organic manure with necessary incentives. Others suggestions were to ensure the availability of pheromone traps and natural enemies in reasonable cost or without cost (44 respondents), and to promulgate clear policies on EFA with necessary incentives and steps (41 respondents).

\section{Results from organic farmers}

1) Farm size, farming age and increased farming income of organic farmers

Small farm size is one of the key features of Bangladeshi farmers. Organic farm size is also not exception of it. Survey results shown in table 5 indicate that average organic farm size of this study area was 0.246

Table 3 Conventional farmers' attitude toward government's role in EFA

\begin{tabular}{|c|c|c|c|c|}
\hline Subjects & Farmers' opinion & $\begin{array}{l}\text { Number of } \\
\text { respondents }\end{array}$ & Percentage & $\begin{array}{l}\text { Likert } \\
\text { value }\end{array}$ \\
\hline \multirow{5}{*}{ Government plays a positive role in EFA } & Strongly agree & 10 & 10 & \multirow{5}{*}{3.27} \\
\hline & Agree & 43 & 43 & \\
\hline & Neutral & 17 & 17 & \\
\hline & Disagree & 25 & 25 & \\
\hline & Strongly disagree & 5 & 5 & \\
\hline \multirow{5}{*}{$\begin{array}{c}\text { Government' s policies and programs are } \\
\text { sufficient for EFA }\end{array}$} & Strongly agree & 3 & 3 & \multirow{5}{*}{2.21} \\
\hline & Agree & 4 & 4 & \\
\hline & Neutral & 29 & 29 & \\
\hline & Disagree & 39 & 39 & \\
\hline & Strongly disagree & 25 & 25 & \\
\hline
\end{tabular}


Role of Government in Environment-friendly Agricultural Development of Bangladesh

Table 4 Farmers' suggested policies and programs on EFA for government's initiatives

\begin{tabular}{c|c|c}
\hline Farmers, suggested policies and programs on EFA & $\begin{array}{c}\text { Number of } \\
\text { respondents }\end{array}$ & $\begin{array}{c}\text { Rank } \\
\text { order }\end{array}$ \\
\hline Extensive training programs on environment friendly agriculture & 64 & 1 \\
\hline Extensive programs on IPM and organic manure with necessary incentives & 58 & 3 \\
\hline $\begin{array}{c}\text { Ensuring the availability of pheromone traps and natural enemies in } \\
\text { reasonable cost or without cost }\end{array}$ & 44 & 4 \\
\hline Clear policies on environment friendly agriculture with necessary incentives and steps & 41 & 3 \\
\hline
\end{tabular}

Note: Here, only disagreed and strongly disagreed farmers $(39+25=64)$ gave their suggestions and they were allowed to select one or more options.

hectare whereas smallest farm size was 0.05 hectare and biggest farm size was 0.80 hectare. Average organic farming age (from how many years they have been practicing organic farming) was 7.63 years (table 5), while lowest farming age was 1 year and highest 17 years. In the similar way, on an average farming income increased $11.4 \%$ (table 5) compared to conventional farming per year where lowest value was $0 \%$ (farming income was not increased) and highest value was $22 \%$ (farming income increased $22 \%$ ).

2) Impact of organic farming on farmers' profitability and livelihood

The results shown in table 6 mention that among the organic farmers $44 \%$ agreed and $40 \%$ strongly agreed about "organic farming is more profitable than conventional farming". The Likert value 4.18 strongly indicated that "organic farming is more profitable than conventional farming". In the similar responses, $44 \%$ organic farmers agreed and 39\% strongly agreed that organic farming had positive impact on their livelihood. The Likert value 4.18 also strongly mentioned that organic farming had positive impact on organic farmers' livelihood. It is observed from

Table 5 Farm size, farming age and increased farming income of organic farmers

\begin{tabular}{|c|c|c|c|c|}
\hline Subjects & Mean value & Standard deviation & Lowest value & Highest value \\
\hline Organic farm size (hectare) & 0.246 & 0.149 & 0.05 & 0.80 \\
\hline Organic farming age (year) & 7.63 & 2.762 & 01 & 17 \\
\hline $\begin{array}{l}\text { Increased farming income compared to conventional } \\
\text { farming (percent per year) }\end{array}$ & 11.4 & 6.611 & 00 & 22 \\
\hline
\end{tabular}

Table 6 Impact of organic farming on farmers' profitability and livelihood

\begin{tabular}{c|c|c|c|c}
\hline \multirow{4}{*}{ Subjects } & Farmers' opinion & Number of respondents & Percentage & Likert value \\
\hline \multirow{4}{*}{$\begin{array}{c}\text { Organic farming is more profitable } \\
\text { than conventional farming }\end{array}$} & Strongly agree & 40 & 40 & 44 \\
\cline { 2 - 4 } & Agree & 44 & 12 \\
\cline { 2 - 4 } & Neutral & 12 & 2 \\
\cline { 2 - 4 } & Disagree & 2 & 2 \\
\cline { 2 - 4 } & Strongly disagree & 2 & 39 \\
\hline \multirow{4}{*}{$\begin{array}{c}\text { Organic farming has positive impact } \\
\text { on farmers' livelihood }\end{array}$} & Strongly agree & 39 & 44 \\
\cline { 2 - 4 } & Agree & 44 & 11 \\
\cline { 2 - 4 } & Neutral & 11 & 4 \\
\cline { 2 - 4 } & Disagree & 4 & 2 \\
\cline { 2 - 4 }
\end{tabular}


this study that some farmers sell their products in local markets and they do not get any price premium but they make profit for lower production costs.

3) Correlation among organic farm size, farming age and farmers' profitability

Table 7 indicates that increased farming income has significant relationship with organic farm size. The small value of $r(-0.4169)$ also indicates that their relationship is weak, and negative (-) value refers a negative or opposite relationship between increased farming income and organic farm size that means rate of farming income increases with decreasing of farm size. Therefore, the result from this study reveals that smaller farm size is suitable for farmers' profitability. Researchers like Setboonsarng (2006) and Scialabba (2000) reported that organic farming is more profitable for smallholders because they have abundant labor forces and experiences. The result also shows that the relationship between farming income and farming age is weak and positive value refers that farming income increases with increasing farming age (farming experience).

Pretty(2002) also argued that organic agriculture can improve the incomes and living standards of poor farmers by building on assets which poor farmers have, i.e., land free from intensive use of chemicals, excess labor, low-cost and locally available technologies, and traditional knowledge of production system. In Bangladesh, maximum farmers are small, marginal and landless who have less than 1.0 hectare of farm land. Farming systems of many of these poor farmers are organic by default. They have high potentiality of practicing organic farming because of easier certification and practicing with their existing resources. Government may use organic farming as a tool of earning foreign currencies and enhancing rural livelihood through utilizing the potentialities of large number smallholders or subsistence farmers of practicing organic agriculture.

4) Marketing and support sources

Marketing and other support services are essential to practice organic farming, especially developing country like Bangladesh where farmers' skill and economic conditions are low. From the results which are mentioned in table 8, it is observed that main source of marketing of organic products was NGO (according to 73\% respondents) and other sources were local markets $(23 \%)$ and whole sellers (4\%). Table 8 also indicates that from NGOs, $66 \%$ organic farmers got technical support, $46 \%$ farmers got financial support and $61 \%$ farmers sought advice for problems related to organic farming. Second important sources of

Table 7 Correlation among organic farm size, farming age and farmers' profitability (Pearson Correlation Coefficients, N=100)

\begin{tabular}{c|c|c}
\hline & Organic farm size & Organic farming age \\
\hline Increased farming income & -0.4169 & 0.38849 \\
$(\mathrm{P}=0.0604)$
\end{tabular}

Table 8 Marketing and support sources

\begin{tabular}{|c|c|c|c|c|}
\hline Activities & Sources & $\begin{array}{l}\text { No. of respondents } \\
\qquad(\mathrm{N}=100)\end{array}$ & Percentage & Rank order \\
\hline \multirow{4}{*}{ Marketing } & Whole sellers & 4 & 4 & 3 \\
\hline & Local markets & 23 & 23 & 2 \\
\hline & NGO & 73 & 73 & 1 \\
\hline & Others & 0 & 0 & 4 \\
\hline \multirow{3}{*}{ Technical support } & $\mathrm{GO}$ & 18 & 18 & 2 \\
\hline & NGO & 66 & 66 & 1 \\
\hline & Others & 16 & 16 & 3 \\
\hline \multirow{3}{*}{ Financial support } & Bank & 20 & 20 & 3 \\
\hline & NGO & 46 & 46 & 1 \\
\hline & Others & 34 & 34 & 2 \\
\hline \multirow{4}{*}{$\begin{array}{l}\text { Sources of advice for problems } \\
\text { related to organic farming }\end{array}$} & Others farmer & 9 & 9 & 4 \\
\hline & Extension services (DAE) & 20 & 20 & 2 \\
\hline & NGO & 61 & 61 & 1 \\
\hline & Others & 10 & 10 & 3 \\
\hline
\end{tabular}


technology support were government's organizations. According to the survey result $18 \%$ farmers got technical support from Government Organization (GO) and 20\% farmers sought advice for problems related to organic farming. In Bangladesh, the main Government Organization for providing technical support is Department of Agricultural Extension (DAE). From the result, it is clearly observed that NGOs are supporting as well as dominating in every sphere of organic sector in Bangladesh. These results are also similar to the findings of researchers like Reunglertpanyakul (2001), and international organizations like FAO (2004) and IFAD (2005) which findings revealed that NGOs played major role in the expansion of organic agriculture in the South and South East Asia.

\section{5) Expected government's role in organic farming}

Government's initiatives are essential in the developing country like Bangladesh where private sectors are not well developed. Organic certification body is highly essential to ensure consumer trust and to maintain equal standard of organic products. But certifying by international certification body is very expensive, time consuming and cumbersome. For domestic or internal marketing of organic products, it is necessary to have at least one government's certification body for ensuring of consumers' trust. According to the table 9, 86\% ('Yes'-46\% and 'absolutely yes'-40\%) farmers gave their strong opinion to have a government's certification body where Likert value was 4.17. In the similar way, 89\% ('Yes'-44\% and 'absolutely yes'-45\%) farmers felt the need of government's initiatives on organic farming where Likert value was 4.25 . From these results, it can be said that government's certification body and other initiatives are highly essential for organic farmers.

What kinds of government's initiatives are necessary for organic farmers? We can find answer of this question from the table 10. According to the organic farmers' opinions, bank loan and market development facilities were the most necessary initiatives (89 respondents, 1st) which government should take. In Bangladesh, maximum farmers are poor and subsistence farmers. They need financial supports as priority based. It is observed that marketing is the crucial issue for practicing organic agriculture. If the government takes initiatives like establishing certification body, procuring organic food for hospitals and other government's institutions, exporting of organic products, then it will be easy to practice organic farming for the farmers.

Organic farmers suggested others initiatives as government's initiations 'extension services' (83 respondents, 2nd), export oriented facilities (71respondents, 3rd) and direct payment as incentives (69 respondents, 4th). Maximum organic farmers of Bangladesh are dependent on NGOs for their technical supports. If government's organization named Department of Agricultural Extension provides more extension services to organic farmers than existing services, then organic farmers will get better services and they will be able to follow better production and marketing directions. World organic market is expanding rapidly and many developing countries are earning foreign currencies through exporting organic products in Europe, America, Japan, Korea and other developed countries. If government takes export oriented initiatives, then Bangladeshi farmers may get remarkable

Table 9 Farmers' opinions on government's role in organic farming

\begin{tabular}{|c|c|c|c|c|}
\hline Subjects & Farmers' opinion & Number of respondents & Percentage & Likert value \\
\hline \multirow{5}{*}{$\begin{array}{l}\text { Farmers' feeling on necessity of } \\
\text { government' s certification body to maintain } \\
\text { equal standard of organic products }\end{array}$} & Absolutely Yes & 40 & 40 & \multirow{5}{*}{4.17} \\
\hline & Yes & 46 & 46 & \\
\hline & Neutral & 7 & 7 & \\
\hline & No & 5 & 5 & \\
\hline & Absolutely No & 2 & 2 & \\
\hline \multirow{5}{*}{$\begin{array}{l}\text { Farmers' feeling on necessity of } \\
\text { government's initiatives on organic farming }\end{array}$} & Absolutely Yes & 44 & 44 & \multirow{5}{*}{4.25} \\
\hline & Yes & 45 & 45 & \\
\hline & Neutral & 5 & 5 & \\
\hline & No & 4 & 4 & \\
\hline & Absolutely No & 2 & 2 & \\
\hline
\end{tabular}


Islam, MD. Mafizul · Hwang, Hancheol

Table 10 Kinds of expected government's initiatives on organic farming

\begin{tabular}{c|c|c}
\hline Kinds of expected government's initiatives & Number of respondents & Rank order \\
\hline Extension services & 83 & 2 \\
\hline Bank loan and market development facilities & 89 & 1 \\
\hline Direct payment as incentives & 69 & 4 \\
\hline Export oriented facilities & 71 & 3 \\
\hline
\end{tabular}

Note: Here, only 'Absolutely Yes' and 'Yes' categories farmers $(44+45=89)$ of table-41 gave their opinions, and they were

allowed to select one or more options.

price premium of organic products and may enhance their livelihood. Many developed countries including Korea provide incentives as direct payment to organic farmers. As Bangladesh is a developing country, so government has no such economic ability to provide more financial incentives to organic farmers. However, government may take direct payment program as pilot project to motivate organic farmers.

\section{Conclusion}

Sustainable agricultural development gained greater attention in recent decades. Meaning of sustainability varies but global consensus has built to ensure it. Environmentfriendly agriculture is considered as a means of sustainable agricultural development and government's role is necessary to promote it. As a developing country, Bangladesh has financial limitations but government has showed its commitment to ensure sustainable agricultural development through reforming policies and taking various programs like, IPM, ICM, biological pest control and soil fertility improvement etc. According to the expectations of farmers, government should take more programs and promulgate policies related to environment-friendly agriculture. Conventional farmers suggested for government's initiatives to take extensive training programs on environment-friendly agriculture, to strengthen IPM programs and to ensure the availability pheromone traps and natural enemies.

Role of government in organic agriculture sector is highly essential in Bangladesh, because private sector is not well developed in this country. Many countries in the world are using organic agriculture as a tool of earning foreign currencies and poverty reduction as well as ensuring agricultural sustainability. Government of
Bangladesh may easily utilize the vast potentialities of large number of resource poor small farmers to practice organic agriculture through creating marketing and exporting facilities, and strengthening financial and technical support services. It is necessary to have at least one government's certification body to maintain equal standard of organic products and to ensure consumer's trust, and same suggestions are also reflected from farmers' opinions of this study. Government of Bangladesh faces conflicting pressures to increase production of food and fibers for over growing populations and to address environmental concern. In this abject state of affairs, government of Bangladesh is looking for sustainable food self sufficiency without poverty and without degradation of natural resources.

\section{References}

1. Anonymous, 1980, Report and Recommendations on Organic Farming-Case Studies of 69 Organic Farmers in USA; Pub. of US Board of Agriculture, USA.

2. Cheung, Y. K. A., 1997, Chapter Two: The Concept of Sustainable Development. An Environmental Assessment Approach for Hong Kong and the Pearl River Delta: Principles and Practices. Ph.D. Thesis, The University of Hong Kong, p. 48.

3. Dumanski, J., 1993. Sustainable Land Management for the 21st Century, Vol. 1, IBSRAM, Bangkok and Agriculture Canada, Ottawa.

4. FAO (Food and Agriculture Organization of the United Nations), 2004. The State of Food and Agriculture: Agricultural Biotechnology; Meeting the Needs of the Poor? Rome: FAO,

5. Greenland, D.J., 1997. The Sustainability of Rice Farming. UK: CAB International. 
6. Hallam, D., 2003. The organic market in OECD countries: past growth, current status and future potential. Organisation for Economic Co-operation and Development: Organic Agriculture: Sustainability, Markets, and Policies. Wallingford, CABI, pp. 179-186.

7. IFAD, 2003. The adoption of organic agriculture among small farmers in Latin America and the Caribbean: Thematic Evaluation. Rome: IFAD.

8. IFAD, 2005. Organic Agriculture and Poverty Reduction in Asia: China and India Focus; Thematic valuation. Report No. 1664. International Fund for Agricultural Development, Rome.

9. IFOAM, 2006. International Federation of Organic Agriculture Movements. (available at www.ifoam.org)

10. IISD (International Institute for Sustainable Development), 1995. Agriculture and Sustainable Development: Policy Analysis on the Great Plains. p.8.

11. Kilcher, L., 2002. Production and trade constraints of organic products from developing countries. In: Proceedings of the 14th IFOAM Organic World Congress, August 2002, pp. 23.

12. Liu, K. and Lu, C., 1992. Sustainable land use and sustainable development: Critical issues. Quoted in Bellamy, M. et al. Issues in agricultural development: Sustainability and cooperation. IAAE Occasional Paper No. 6. International Association of Agricultural Economists. London, pp. 322-329.

13. Makatouni, A., 2002. What motivates consumers to buy organic food in the UK?: Results from a Mc Neely, J.A., and Scherr, S.J., Eco AgricultureStrategies to Feed the World and Save Wild Biodiversity. Island Press, Washington, USA.

14. Mc Neely, J.A., and Scherr, S.J., 2002. Eco Agriculture-Strategies to Feed the World and Save Wild Biodiversity. Island Press, Washington, USA.

15. Ming, G., 2003. Sustainability analysis of farming systems in Dafang county, Guizhou province, People's Republic of China. PhD thesis, p. 23.

16. MOA (Ministry of Agriculture), 2010. 'Agricultural Statistics'. Ministry of Agriculture, Government of the People's Republic of Bangladesh.

17. MOA, 2002. 'National Integrated Pest Management Policy'. Ministry of Agriculture, Government of the
People's Republic of Bangladesh.

18. MOA, 2008. 'National Agriculture Policy (Draft 3)'. Ministry of Agriculture, Government of the People's Republic of Bangladesh.

19. Pretty, J. N., 1995b. Participatory learning for sustainable agriculture. World Development, 23 (8), 1247-1263.

20. Pretty, J.N., 1995a. Regenerating agriculture: policies and practice for sustainability and self reliance. Earthscan Publication Ltd., London.

21. Pretty, J.N., 2002. 'Lessons from Certified and Non-Certified Organic Projects in Developing Countries.' In Organic Agriculture, Environment and Food Security, edited by Nadia Scialabba and Caroline Hattam. Rome: Food and Agriculture Organization of the United Nations.

22. Reunglertpanyakul, V., 2001. "National Study: Thailand". Paper on organic farming in Asia resented at the United Nations Economic and Social Commission for Asia and the Pacific regional workshop, "Exploring the Potential of Organic Agriculture for Rural Poverty Alleviation in Asia and the Pacific", Chiang Mai, Thailand, 26-29 November, 2001.

23. RocSearch Ltd., 2004. Global Organic Food Market, London: RocSearch Ltd.

24. Scialabba, N., 2000. Factors influencing organic agriculture policies with a focus on developing countries. In IFOAM 2000 Scientific Conference, Basel, Switzerland. (available at www.fao.org/organicag/doc/BaselSum-final.doc)

25. Scialabba, N., and Hattam, C., 2002. General concepts and issues in organic agriculture. In Organic agriculture, environment and food security, ed. $\mathrm{N}$. Scialabba and C. Hattam. Environment and Natural Resources Series No. 4. Rome: Food and Agriculture Organization of the United Nations.

26. Setboonsarng, S. 2006. Organic Agriculture, Poverty Reduction, and the Millennium Development Goals, ADB Institute Discussion Paper No. 54.

27. Setboonsarng, S., Leung, P., and Ca,i J., 2005. 'Contract Farming and Poverty Reduction: the Case of Organic Rice Contract Farming in Thailand' ADBI Discussion paper No. 49. Tokyo: ADBI.

28. Setboonsarng, S., 2004. Roles of Contract Framing in 
Poverty Reduction. On-going Research in Lao PDR and Cambodia under RETA 6112, Making Markets Work Better for the Poor. Presentation at the Regional Research Workshop on Contract Farming and Poverty Reduction: Issues and Research Methodology, Bangkok, Thailand, 9-12 August, 2004.

29. Smith, E. G., Clapperton, M. J. and Blackshaw, R. E., 2004. Profitability and risk of organic production systems in the northern Great Plains. Renewable Agriculture and Food Systems, 19, 152-158.

30. Stoll, G., 2002. Asia and the International Context. Organic agriculture and rural poverty alleviation: Potential and best practices in Asia. Bangkok: United Nations Economic and Social Commission for Asia and the Pacific.

31. UNCED (United Nations Conference on Environment and Development), 1992. Agenda 21.

32. Vasavada, U., 1991. "Trade Policy Implications of Sustainable Agriculture", Canadian Journal of Agricultural Economics, Vol.39, No. 4, Part 1. p. 595.

33. Vindigni, G., Janssen, M. A., and Jager, W., 2002. Organic food consumption: A multi-theoretical framework of consumer decision making. British Food Journal, 104, 624-642.

34. Von Braun, J., Hotchkiss, D., and Immink, M., 1989. Nontraditional Export Crops in Guatemala: effects on production, income and nutrition. Research Report No. 73. Washington, D.C., International Food Policy Research Institute.

35. Willer, H., and Yussefi, M., 2007. The World of Organic Agriculture-Statistics and Emerging Trends 2007. International Federation of Organic Agriculture Movements IFOAM, Bonn, Germany and Research Institute of Organic Agriculture FiBL, Ackerstrasse, Switzerland.

36. World Bank, 2011. Household Income and Expenditure Survey 2010 Results of Bangladesh Published. (available at:

http://www.worldbank.org.bd/WBSITE/EXTERNAL/CO UNTRIES/SOUTHASIAEXT/BANGLADESHEXTN/0,,c ontentMDK:22946585 menuPK:295765 pagePK:286506 6 piPK:2865079 theSitePK:295760,00.html)

37. Yussefi, M. and Willer, H., 2003. The World of Organic Agriculture Statistics of 2003 and Future Prospects. Retrieved from www.ifoam.org.

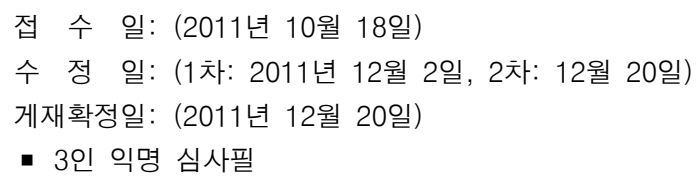

